to whether refusal of treatment does or does not comprise a danger to the self but, clearly, we are not seen adequately to be emphasising the essence of the 1983 Mental Health Act. Therein it is clear that compulsory detention and appropriate treatment in hospital of someone resisting such medical advice relating to their condition is only taken in the interests of their health or safety or for the protection of others. We are examining ways of printing an appropriate correction to the present text and will correspondingly change the text itself in the first reprint. In the meantime, we are making this latter change now to the text which shortly will be published on the College's website.

A. H. CRISP, Changing Minds Campaign Management Committee and Professor of Psychiatry, Psychiatric Research Unit, Atkinson Morlay's Hospital, 31 Copse Hill, Wimbledon, London SW20 ONT

\section{Use of placebo}

Sir: "There are only a few articles published on the use of placebo, either for diagnostic or treatment purposes; one notable and helpful example being Miller (1988)" (Cooney. Psychiatric Bulletin. January 1999, 22, 53-54). Your correspondent must be referring only to diagnosis, for even if reports on placebo-controlled clinical trials are ignored, a search of Medline or the Cochrane Collaboration Library would list many publications on placebo therapy.

False modesty prevents direct reference to my own publications, but there have been several later articles on aspects of placebo treatment in the Lancet in 1994 (further details available from the author upon request), for example; and Shepherd \& Sartorius (1989) have edited a comprehensive volume on Non-Specific Aspects of Treatment that deals in even more general terms with the topic. Attention may also be directed to the proceedings of a recent symposium (Schmidt, 1998).

SCHMiDT. J. G. (1998) Placebo-valuable if it helps the patient? Research in Complementary Medicine, 5 (suppl. 1). 102-111.

SHEPHERD, M. \& SARTORIUS. N. (eds) (1989) Non-Specific Aspects of Treatment. Toronto: Huber and Geneva: WHO.

C. R. B. JOYCE, Department of Psychology, Royal College of Surgeons in Ireland, Mercer St Lower, Dublin 2, Ireland

\section{Women in Psychiatry Special Interest Group}

Sir: I was interested to read the survey by Blower (Psychiatric Bulletin, January 1999, 23, 24-29) concerning staff grade psychiatrists, of whom the majority would appear to be female. The Women in Psychiatry Special Interest Group would like to encourage any staff grade psychiatrists who are Members, Affiliates or Inceptors of the College to join this group, which can be done in the usual way by contacting the College. The aims of the Group are to support and promote the careers of women psychiatrists and the health needs of female patients with mental illness.

Anne Cremona, Chairman, Women in Psychiatry Special Interest Group, 2 Maids of Honour Row, Richmond-upon-Thames, Surrey TW9 INY

\section{Inappropriate antidiuretic hormone secretion associated with zopiclone}

Sir: The syndrome of inappropriate antidiuretic hormone (SIADH) is a well recognised complication of many psychotropic drugs (Thomas \& Verbalis, 1995). Reports of an association with benzodiazepines are uncommon (Engel \& Grau, 1988). To our knowledge this is the first report of SIADH associated with zopiclone, a cyclopyrrolone hypnotic which acts at benzodiazepine receptors.

A patient was treated by a general practitioner with zopiclone $7.5 \mathrm{mg}$ nightly for a two-week history of insomnia. Over the next nine days the patient became confused, lethargic and depressed, culminating in an overdose of six zopiclone tablets. The previous medical history included hypertension controlled by felodipine $5 \mathrm{mg}$ daily for the past two years. The patient had suffered two previous episodes of diureticinduced SIADH which were confirmed by measurements of serum and urine osmolality.

On admission serum sodium was $129 \mathrm{mmol} /$ $\mathrm{L}$, falling to $113 \mathrm{mmol} / \mathrm{L}$ four days later. Serum osmolality was low at $240 \mathrm{mmol} / \mathrm{kg}$ and urine sodium was $20 \mathrm{mmol} / \mathrm{L}$ suggesting a further episode of SIADH. All other investigations were normal. Psychiatric assessment revealed mild cognitive impairment and depressive features which resolved spontaneously as the serum sodium returned to normal, 12 days after discontinuation of zopiclone.

The rapid resolution of symptoms and correction of hyponatraemia after discontinuation are consistent with this being related to prescription of zopiclone. Furthermore investigations excluded other causes of SIADH. 'Rechallenge to confirm' was considered 
inappropriate, particularly as this was the patient's third episode of drug induced SIADH. The temporal relationship between the institution of zopiclone and the onset of hyponatraemia seem to support a causal link.

ENGEL. W. R. \& GRAU, A. (1988) Inappropriate secretion of antidiuretic hormone associated with lorazepam. British Medical Journal, 297, 858.

THOMAS. A. \& Verbalis, J. G. (1995) Hyponatraemia and the syndrome of inappropriate antidiuretic hormone secretion associated with drug therapy in psychiatric patients. CNS Drugs, 41, 357-369.

S. A. CuBBIN, Senior House Officer, and I. M. ALI, Senior Registrar, Cefn Coed Hospital, Waunarlwydd Road, Cockett, Swansea SA2 OGH

\section{Mental health review tribunals' role in assessment of dangerousness: a cause for concern}

Sir: A recent experience made me aware of a serious defect in the tribunal system. I saw a woman on a domiciliary visit. She had already that day attacked two other people. At first she was mute, then got up and came back with a plank of wood and assaulted me with it.

After admission, under Section 2, she calmly said that she had intended to fracture my skul and rationalised that I would have acted similarly to a stranger coming into the house not wearing an identification label. She also exhibited grandiose delusions. Depot antipsychotic medication was necessary. She also showed low thyroid functioning and thyroxine was started. She appealed and appeared before the mental health tribunal. Her mental state was unchanged and she again gave her rationalised reasons for her aggression. She showed no insight.

The tribunal made her informal, on their doctor's grounds that she had hypothyroidism that could be treated at home. Also as hypothyroidism was seen as the cause of the psychosis, antipsychotic medication was not felt to be required. The dangerousness was ignored. The other panel members had accepted the doctor's evaluation.

I submitted an official complaint. It was forwarded to the regional chairman of the mental health review tribunal. We then, informally, discussed the situation. The feedback was:

(a) Tribunals cease to exist or function once the case has been heard. In other words, there is no machinery to feedback concerns about the decision.

(b) There was no money available from Government sources to train, and monitor the standard and quality of the work of the members of the tribunal. (c) I was advised that our local mental health trust could take the decision before a judiciary but that would be a lengthy and expensive procedure.

The case highlights a potentially serious loophole in our ability to keep patients in hospital, when in clearly dangerous states of mind.

There is a need for a regular review of the level of competence of board members, and the need to provide refresher courses, where examples like the one given, could be used for teaching purposes.

R. N. LuCAS, Consultant Psychiatrist, St. Ann's Hospital, St Ann's Road, London N15 3TH

\section{The hare and the tortoise}

I must have heard this story when I was a child, how the hare was distracted from his goal by various adventures and great fun, while the tortoise, in a determined, boring, persistent way, reached the end of the race. I never thought then that I would identify with this story and live through it.

Like the hare, I spent my years in the medical school, I passed every year with honours, hopeful about the future, and looking forward to the future as a practising physician.

The final year in the medical school was dramatic. A strange attack of diplopia which lasted for a couple of months and resolved spontaneously, the MBBCh with honours several months later, and soon afterwards generalised weakness in the right lower limb which persisted despite intensive physiotherapy. Several months later, with various investigations and provocative neurological tests, I was diagnosed as suffering from multiple sclerosis: no cause, no treatment and the prospects of physical deterioration and incapacity.

The era of the hare came spontaneously to an end as I had to adopt the challenging qualities of the tortoise: perseverance, patience, determination, to do my best in order to reach my goal. I proceeded as a psychiatric senior house officer in a reasonable degree of physical health, no walking aids and success in obtaining the first part of the MRCPsych. The following couple of years as a registrar proceeded with a relative degree of reasonable physical health, now using a walking stick and I obtained the final part of the MRCPsych qualification. I was very grateful to God that I had reached what I thought was my goal, but was it?

I proceeded through the following years with two elbow crutches and the equivalent of high psychiatric training. Now I am a consultant, still on the elbow crutches, my speed is not very different from that of the tortoise. I am not as 